\section{'Amiga' Strawberry}

Carmen Soria ${ }^{1}$, José F. Sánchez-Sevilla, María T. Ariza, Josefa Gálvez,
and José M. López-Aranda
Centro IFAPA de Churriana, Junta de Andalucia, 29140 Málaga, Spain

Juan J. Medina and Luis Miranda

Centro IFAPA Las Torres-Tomegil, Junta de Andalucia, 21800 Moguer, Huelva, Spain

Antonio Arjona

Viveros California, S.L., C/Paseo de las Delicias 5-4, 41001 Seville, Spain

Rafael Bartual

Instituto Valenciano Investigaciones Agrarias (I.V.I.A.), 46113 Moncada (Valencia), Spain

Additional index words. Fragaria $\times$ ananassa, fruit breeding, cultivar

'Amiga' is a short-day strawberry cultivar developed by the Spanish public breeding program. 'Amiga' has a very high fruit firmness, high production, long fruit shape, and good appearance. An agronomic and sensory characterization of this new cultivar, in comparison with the well-adapted cultivars Camarosa, Carisma, Marina and Medina, was undertaken during the 2000 and 2001 crop seasons.

Most strawberries produced in Spain are shipped fresh to destinations throughout Europe. Growers therefore need cultivars producing fruit that, in addition to attractiveness and top-class sensory attributes, ensures maintenance of quality after long-distance shipment. During the crop season 2006, a total of $58.3 \%$ of the total strawberry output at Huelva $(312,066 \mathrm{t})$ was shipped fresh to market (Anonymous, 2006). The main destinations were Germany, France, and the United Kingdom.

As a result of the economic and social significance of strawberry production in Spain, which is currently the leading European producer of fresh-market strawberries (López-Aranda et al., 2003), a number of public institutions, including the Instituto Nacional de Investigaciones Agrarias (INIA), the Instituto de Investigación y Formación Agraria y Pesquera (IFAPA), and the Instituto Valenciano de Investigaciones Agrarias (IVIA), are carrying out a breeding program to develop new strawberry cultivars well adapted to growing conditions in Spanish production areas, and particularly in Huelva. 'Amiga' is the latest cultivar released from this program in cooperation with the private partner, Viveros California, S.L. Previous

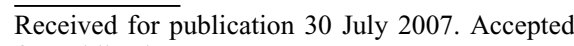
for publication 31 Oct. 2007.

This research was funded by INIA Project SC98035-C2-2 and INIA Agreement CC05-024-C3-1.

We thank Mr. Paul Edson for the English revision. ${ }^{1}$ To whom reprint requests should be addressed; e-mail maria.soria@juntadeandalucia.es
}

cultivars released include 'Andana' (Bartual et al., 1997), 'Carisma' (Bartual et al., 2002), 'Marina' (López-Aranda et al., 2004), 'Medina' (López-Aranda et al., 2005a), and 'Aguedilla' (López-Aranda et al., 2005b).

The new short-day strawberry (Fragaria $\times$ ananassa Duch.) cultivar Amiga is remarkable for its very high firmness, high production in annual production systems, long fruit shape, and good appearance. Its harvest season is early, which is extremely important for economic production on the southwest coast of Spain, and its firmness is essential for long-distance shipment.

\section{Origin}

'Amiga', was selected in 1998 from the offspring of a cross between 'Camarosa' and 'selection 3-79' and was tested as 'selection 2-269' over the following years. 'Camarosa', a University of California cultivar (Voth et al., 1994; U.S. Plant Patent no. 8708), was used as the female parent because of its outstanding adaptability to the Huelva production area and its high yield. Spanish breeding program 'selection 3-79', which resulted from a cross between 'Vilanova' and the Israeli 'selection I-104', was used as the male parent because of its very good fruit appearance and notable earliness.

'Selection 2-269' was propagated in high-elevation nurseries ( $900 \mathrm{~m}$ altitude) in Castilla-León (central Spain) and was subsequently evaluated in replicated plot trials at Moguer (Huelva).

\section{Description}

'Amiga' is an early short-day strawberry cultivar. It is a vigorous plant that tends to produce numerous runners with low anthocyanin coloration and medium pubescence when planted in mid-April in high-elevation nurseries in Castilla-Leon (900 to $1000 \mathrm{~m}$ altitude). It has a flat, globose growth habit and medium plant density.
Leaf size is similar to that of 'Camarosa'. Leaves are strongly to slightly concave and have weak blistering with three medium green, medium glossy leaflets. The terminal leaflet is longer than wide with an obtuse base and crenate margins. Inflorescences are produced on long peduncles and are positioned above the leaf canopy. Flower size is large and the calyx diameter is larger than the corolla. The corolla has five white petals, as long as broad, that overlap. Fruit are very firm, mostly wedge-shaped, and much longer than broad. Fruit size is large and constant throughout the fruiting season. The external color of fully mature fruit is red and medium glossy (Fig. 1). The fruit surface is even and achenes are inserted at surface level. Within the fruit, flesh color is medium red and the internal cavity is weakly expressed. The calyx is firmly attached to the fruit and is much larger than the diameter of the fruit. Fruit flavor at full ripeness is excellent and pleasantly aromatic.

Postharvest testing showed that 'Amiga' has a good shelf life, similar to that of 'Camarosa'.

'Amiga' has proved to be a productive cultivar with very high early and total yields of first quality and very firm fruits. Fruit ripening occurs early in the season, thus coinciding with the economic requirements of southern European growers.

\section{Performance}

Fruit production and quality of 'Amiga' was compared with four other early shortday strawberry cultivars at Moguer (Huelva, Spain) during crop seasons 2000 and 2001. To reduce the presence of soil pathogens, soil was solarized + biofumigated (MedinaMínguez, 2002) before planting. During the last week of the previous October, each cultivar was planted in three completely randomized plots of 70 plants each on tworow raised beds covered with black plastic. Plants were spaced $0.25 \times 0.25 \mathrm{~m}$ apart and covered by large plastic $(150 \mu)$ tunnels ( $6.6 \mathrm{~m}$ wide $\times 3.5 \mathrm{~m}$ high $\times 70 \mathrm{~m}$ long $)$. Marketable fruit were harvested and weighed 28 times from 18 Jan. to 23 May 2000 and 23 times from 29 Jan. to 22 May 2001. Individual fruit weight was calculated by dividing the total yield by the total number of harvested fruits. Three fruits per plot were

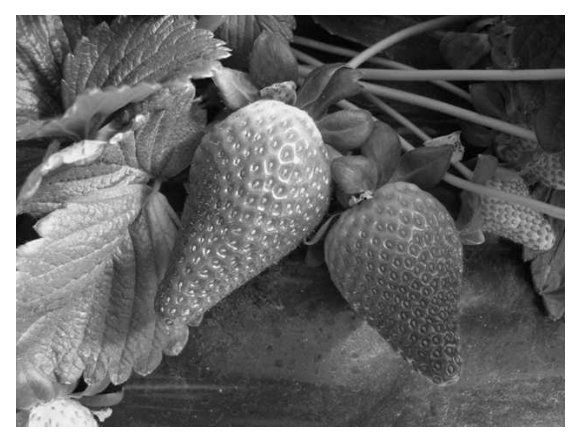

Fig. 1. Fruits of 'Amiga' strawberry. 
Table 1. Marketable yield and fruit quality of 'Amiga' and four other strawberry cultivars grown in Huelva, Spain, during the 2000 and 2001 crop seasons.

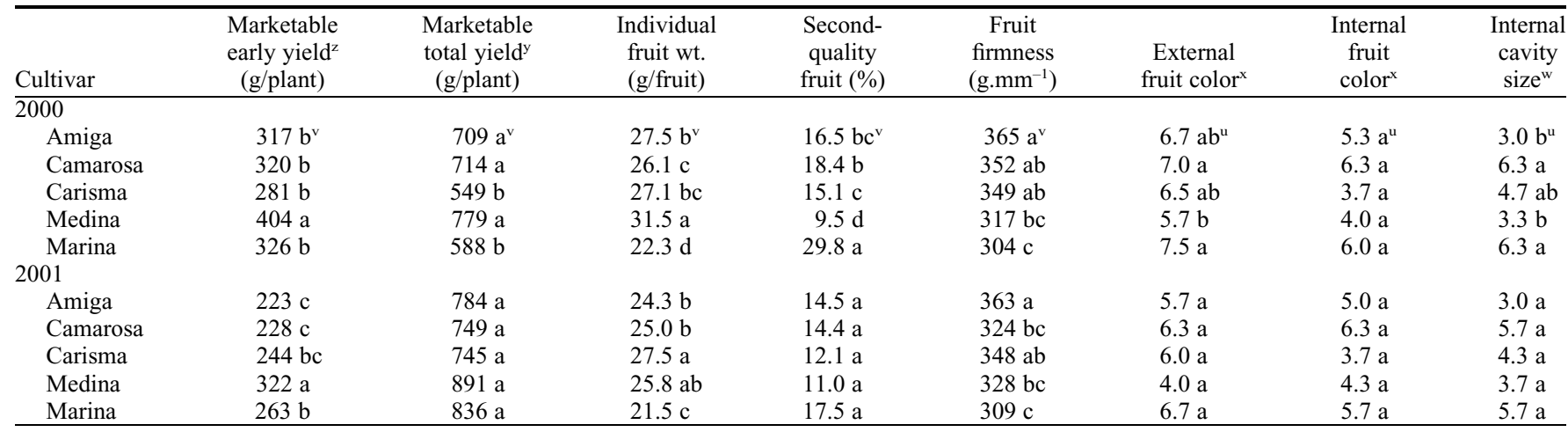

${ }^{2}$ Early yield: from 1 Jan. until end of March.

${ }^{\mathrm{y}}$ Total yield: from 1 Jan. until end of May.

${ }^{\times}$Rated on a scale from 1 to 9 , where $1=$ light red and $9=$ deep red.

"Rated on a scale from 1 to 9 , where $1=$ absent and $9=$ large internal cavity throughout the fruit.

${ }^{v}$ Within columns for each season, means followed by different letters are significantly different at $P \leq 0.05$ as determined by Fisher's least significant difference test.

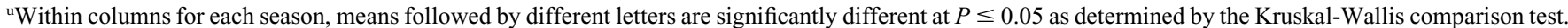

Table 2. Shelf life parameters of 'Amiga' and four other strawberry cultivars grown in Huelva, Spain.

\begin{tabular}{lccc}
\hline Cultivar & $\begin{array}{c}\text { Fruits brightness } \\
(\%)\end{array}$ & $\begin{array}{c}\text { Calyx } \\
\text { freshness }\end{array}$ & Bruising $^{\mathrm{x}}$ \\
\hline Amiga & $4.6 \mathrm{a}^{\mathrm{w}}$ & $5.3 \mathrm{a}$ & $6.3 \mathrm{a}$ \\
Camarosa & $4.6 \mathrm{a}$ & $4.6 \mathrm{a}$ & $4.3 \mathrm{a}$ \\
Carisma & $4.0 \mathrm{a}$ & $6.7 \mathrm{a}$ & $5.0 \mathrm{a}$ \\
Medina & $4.3 \mathrm{a}$ & $5.6 \mathrm{a}$ & $6.0 \mathrm{a}$ \\
Marina & $4.3 \mathrm{a}$ & $5.0 \mathrm{a}$ & $5.3 \mathrm{a}$ \\
\hline
\end{tabular}

${ }^{2}$ Rated on a scale from 3 to 7 , where $3=$ low fruit brightness and $7=$ high fruit brightness.

${ }^{y}$ Rated on a scale from 3 to 7 , where $3=$ low calyx freshness and $7=$ high calyx freshness.

${ }^{x}$ Rated on a scale from 3 to 7 , where $3=$ not bruised and $7=$ highly bruised.

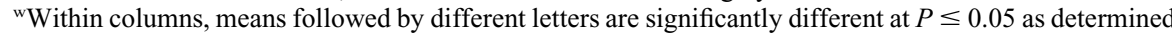
by the Kruskal-Wallis comparison test.

evaluated three times throughout the cropping season (mid-February, mid-March, and mid-May) for external and internal color, internal cavity size, and firmness. Color and cavity size were subjectively rated on a visual scale (see Table 1). Fruit firmness was measured using a penetrometer (Effegi, Italy, Model DT $101 ; \mathrm{Kg} 1 \times 10 \mathrm{~g}$ ) with a 3.5-mm tip.

To estimate the shelf life of 'Amiga' in comparison with the other four cultivars, three times during 2001 season, $500 \mathrm{~g}$ of mature fruit per plot were maintained in cold chamber $\left(4^{\circ} \mathrm{C}\right)$ during $3 \mathrm{~d}$ and then $2 \mathrm{~d}$ at room temperature before evaluate fruit brightness, calyx freshness, and resistance to bruising.

Data were subjected to analysis of variance using Statistix 8.0 software (Analytical Software, Tallahassee, FL) and means were separated at the 0.05 level using Fisher's least significant difference test or the KruskalWallis comparison test (for subjective data). The percentage of second-quality fruit was arsine-transformed before statistical analysis.

Results obtained when comparing yield and fruit quality of 'Amiga' with those of the other four strawberry cultivars are shown in Table 1. 'Amiga' produced nearly $51 \mathrm{t} \cdot \mathrm{ha}^{-1}$ of marketable fruit during 2000 and $57 \mathrm{t} \cdot \mathrm{ha}^{-1}$ during 2001, and in both seasons, it was as productive as 'Camarosa'; its intermediate percentage of second-quality fruit was similar to 'Camarosa' and 'Carisma' in 2000 and that of all cultivars in 2001. Average fruit weight was significantly smaller than 'Medina', larger than 'Camarosa' and 'Marina', and similar to 'Carisma' in 2000; in 2001, it was smaller than 'Carisma', larger than 'Marina', and the same size as the remaining cultivars. The external red color of mature 'Amiga' fruits was fairly stable over the crop season; the internal color tended to be medium red. The internal cavity in the fruit was weakly expressed, and in no case did it lead to cracking to the outside of the fruit. 'Amiga' was remarkable for its very high fruit firmness, significantly higher than that of 'Medina' and 'Marina' in both crop seasons, and also higher than 'Camarosa' in 2001.

All the cultivars showed a good shelf-life behavior. After $5 \mathrm{~d}$ of storage $\left(3 \mathrm{~d}\right.$ at $4{ }^{\circ} \mathrm{C}$ and $2 \mathrm{~d}$ at room temperature), no significant differences were found for fruit brightness, calyx freshness, or resistance to bruising among the cultivars tested (Table 2).

'Amiga's susceptibility to powdery mildew (Sphaerotheca macularis Walls ex Fr.) and to the two-spotted spider mite (Tetranychus urticae Koch) in natural field conditions was low and similar to that of 'Camarosa'.

\section{Availability}

IFAPA, INIA, IVIA, and Viveros California, S.L. have jointly applied for inscription in the Register of Commercial Strawberry Varieties (Spanish Plant Variety
Office, application number 20060134) and for a Community Plant Variety Right (CPVR) in the European Union territory. Parties interested in propagating this cultivar should contact Viveros California, S.L., Paseo de las Delicias 5-4º 41001 Seville, Spain.

\section{Literature Cited}

Anonymous. 2006. Boletín de Información Agraria y Pesquera. Consejería de Agricultura y Peca. Dec. 2006. <http://www.cap.junta-andalucia.es>.

Bartual, R., J.M. López-Aranda, J.I. Marsal, J.J. Medina, J. López-Medina, and R. LópezMontero. 1997. Calderona: A new public Spanish strawberry cultivar. Acta Hort. 439: 261-267.

Bartual, R., J.I. Marsal, J.M. López-Aranda, J.J. Medina, R. López-Montero, A. Arjona, and J. López-Medina. 2002. Carisma: A new Spanish strawberry cultivar. Acta Hort. 567:187-189.

López-Aranda, J.M., J.J. Medina, J.I. Marsal, and R. Bartual. 2003. Strawberry production in Spain, p. 230-237. In: Childers, N.F. (ed.). The strawberry. A book for growers, others. Dr. Norman F. Childers Publications, University of Florida, Gainesville, FL.

López-Aranda, J.M., C. Soria, J.F. SánchezSevilla, J. Gálvez, J.J. Medina, A. Arjona, J.I. Marsal, and R. Bartual. 2004. 'Marina' strawberry. HortScience 39:1776-1777.

López-Aranda, J.M., C. Soria, J.F. SánchezSevilla, J. Gálvez, J.J. Medina, A. Arjona, J.I. Marsal, and R. Bartual. 2005a. 'Medina' strawberry. HortScience 40:482-483.

López-Aranda, J.M., C. Soria, L. Miranda, J.F. Sánchez-Sevilla, J. Gálvez, R. Villalba, F. Romero, B. De Los Santos, J.J. Medina, J. Palacios, E. Bardón, A. Arjona, A. Refoyo, A. Martínez-Treceño, A. De Cal, P. Melgarejo, and R. Bartual. 2005b. 'Aguedilla' strawberry. HortScience. 40:2197-2199.

Medina-Mínguez, J.J. 2002. Soil solarization and biofumigation in strawberry in Spain. Proc. International Conference on Alternatives to Methyl Bromide. The Remaining Challenges, Seville, Spain. p. 123-125.

Voth, V., D.V. Shaw, and R.S. Bringhurst. 1994. Strawberry plant called 'Camarosa'. U.S. Patent 8,708. U.S. Patent and Trademark Office, Washington, DC. 